Анатолій Пипич. Пост-некласичний синтез знання і соціальна наука

DOI: https://doi.org/10.31874/2309-1606-2019-25-2-9

УДК: 168:37.014.5

\title{
Анатолій Пипич
}

\section{Пост-некласичний синтез знання і соціальна наука}

\section{Анотація}

Автор виходить з традиційності бачення специфіки соціального від поглядів неокантіанців і Дільтея до розрізнення „һитапities”

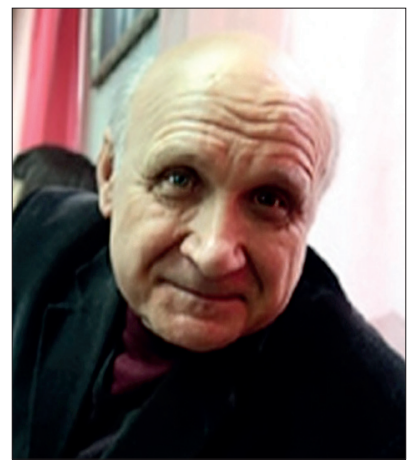
та „sсіепсе”. Передусім розбіжність ия долається через синтез знання про людину і природу. Прикладом є соціобіологія. В межах некласичного і постнекласичного різновидів наукового знання тенденція до теоретичного синтезу наростає. Згадуються кібернетика і синергетика, як орієнтовані на новий тип раціональності і вже у витоках по суті синтетичні.

Особливого значення в цілісній картині світу за думкою автора має соціальне знання, перформативне за своєю природою. Його теоретичний синтез через наявність великої кількості різних концепцій соціального, що було позначено як його багатопарадигмальність, утруднений. Наявний в літературі підхід до його систематизації, за думкою автора, не сприяє вирішенню проблеми. Особливо маючи на увазі не можливість в картині світу врахувати вплив на процес синтезу не тільки знання про людину та природу, а i технічного знання.

Пропонується повернутись до витоків самого поняття парадигми у Т.Куна, його не тільки історичного (парадигми змінюються в часі) але й логічного аспекту (того, що вони внутрішньо пов'язані між собою). Як приклад наводиться теорія відносності А.Ейнштейна, де цей зв'язок двох парадигм (принципи відносності Галілея-Ньютона і Ейнштейна) складає єдність через взаємозв'язок загальної і спеціальної теорії відносності.

На підставі чого автор пропонує взяти за взірець зазначену вище структуру для побудови синтетичної теорії соціального, в якій спеціальна і загальна теорія соціального складали б певну цілісність. Перша частина (спеціальна теорія) мала б прямий стосунок до людини, а у друга б розглядала людські стосунки з урахуванням знання про природу та техніку ( загальна теорія соціального).

Ключові слова: специфіка соціального знання. „humanities” ma „science”, теоретичний синтез знання, наукова картина світу, парадигма, багатопарадигмальмальність, спеціальна і загальна теорія соціальності. 


\section{Проблема специфіки соціальної науки}

Традиційно усі публікації з методології соціальної науки містять згадку про її специфіку. Те ж стосується і підручників з соціології. Ця тема особливого статусу суспільних наук в системі наукового знання безумовно має прямий стосунок і до філософії науки, і до освіти. Тобто $€$ дотичною до відповідної дослідницької роботи та викладання цих наук, зокрема у вищій школі. I передусім про особливості суспільних та гуманітарних наук говорять у їх порівнянні з науками природничими.

Починаючи 3 неокантіанства (розрізнення ідеографічних та номотетичних наук) та Дільтея з його жорстким відокремленням наук про природу від наук про дух, думка про специфіку наук, які мають прямий стосунок до людини („humanitis”) і тих, які досліджують власне природу („science”), стало загальним місцем. I з того часу очевидна тенденція до їх зближення, зокрема пов'язана з процесом математизації соціальногуманітарного знання, то прискорювалась, то знову сповільнювалась.

Зокрема це стосується і соціології. 3 одного боку, вона визначається, приміром, «як систематичне вивчення людських суспільств» (Джери Д., Джери Д.1999, а.) , а, з іншого - у визначенні соціального цю характеристику розповсюджують за межі власне людських спільнот, зазначаючи, що вона має стосунок не лише «до людської інтеракції і/або в організаціях, групах», а і до «(Деяких комах і тварин, включно з людським родом), що живуть разом в організованих колоніях або групах...» (Джери Д., Джери Д., 1999, b). Тобто, предметне поле соціології як науки таким чином з одного боку звужується до людських спільнот, з іншого - явно розширюється за рахунок вже й не-людей, специфічних не-людських соціальних утворень.

Таким чином знову відтворюється та сама, складна і досі не вирішена проблема співвідношення наукового знання про людину („humanitis”) i природу („science”) у їх співвідношенні. А це означає, що зокрема з соціальними науками, усе виявляється багато складніше ніж пропонує зазначене вище, здавалося б дуже чітке і зрозуміле розрізнення, яке вказує начебто на очевидну специфіку соціально-гуманітарного знання стосовно знання природничо-наукового.

Та і сама соціологія, особливо у її емпірико-експериментальній складовій, отримавши суттєвий поштовх розвитку з боку так званої «науки про поведінку», межі, позначені вище, фактично, якщо не долає, то схильна ігнорувати. Зокрема це виявилось у стрімкому розвитку в середині минулого століття, напрямку досліджень, що отримав назву «соціобіологія» ( Джери Д., Джери Д., 1991, с; Харрисон, 1979). I сьогодні цей напрямок продовжує себе позиціонувати як щось середнє між соціологією і біологією - як спроба через синтез цих двох наукових підходів подолати обмеженість їх обох. 
Інакше кажучи, фактично йдеться про синтез соціології як науки, що в центрі уваги має специфічну, соціальну поведінку людей і науки про поведінку у «спільнотах» не тільки людей, а і тварин - приматів, комах, птахів і таке інше. I хоча такого роду дослідження чи не відразу потрапляють під жорстку критику, сам їх бурхливий розвиток свідчить про наявність проблеми розуміння соціального як характеристики не тільки людської, а й не людської поведінки.

Як щодо критики, то вона зосереджується передусім на тому, що, застосовуючи понятійний апарат соціології та психології до аналізу поведінки тварин, ми якраз й ігноруємо вище зазначену специфіку. Таке застосування на думку критиків зворотною стороною має той самий редукціонізм, проти якого власне і були спрямовані усі потуги вказаного вище розрізнення „humanitis” $і$ „,science”.

У зв'язку з чим виникає очевидне питання: якщо ми говоримо, приміром, про альтруїзм, емпатію чи «дружні стосунки» тварин (не кажучи вже про роботів чи інопланетян), то чи будуть за суттю це ті самі ознаки, за допомогою яких ми начебто так само характеризуємо і людську поведінку? А «соціальні» структури комах, неймовірно схожі на дуже спрощені людські, передусім функціями, які виконують в них окремі особини. Це ті самі чи тільки схожі на людські, а за суттю зовсім інші структури?

3 іншого боку, не можна обійти і питання, яким чином пояснення природи цих, за багатьма ознаками «соціальних» якостей і функцій у тварин, можуть буди застосовані до їх людських аналогів? Та сама теорія Дарвіна чи навіть її критика, скажімо в межах соціобіології, можуть бути застосовані для пояснення людської поведінки, чи це знову спроба відродження не дуже шанованого у науковців «соціального дарвінізму»?

\section{Науковий метод та проблема синтезу у пост-некласичній науці}

Виникає й інше питання: чи методи, які ми застосовуємо для вивчення поведінки людини і тварини, мають відрізнятися? Якщо так, то чи вправі ми знання, отримане в результаті застосування цих методів, також ототожнювати чи ні? 3 одного боку, очевидно, що горила чи шимпанзе не відповідають на питання анкети, а тому метод „долученого спостереження" тут буде очевидно більш адекватним. Але, з іншого боку, той самий метод ми можемо застосувати і до вивчення людської поведінки, скажімо, спільноти вчених (Латур, 2015). I чи можна буде тоді прямо порівняти результати відповідних наукових досліджень?

А коли йдеться про дослідження у спільнотах так званих примітивних народів? Зрозуміти поведінку чи окремі дії людей які знаходяться на різних стадіях цивілізаційного розвитку не менш складно. А тому на- 
бір методів вивчення їх соціальної поведінки не може ні повністю збігатися з тими, які застосовуються для вивчення сучасного суспільства, ні кардинально різнитися, якщо ми хочемо залишитись в межах власне антропології.

А якщо ми виходимо за межі соціальної антропології, то опиняємось перед проблемою дослідження «спільнот» ніяк не людських. Але чи тоді ми залишаємось в межах дослідження соціального як певного феномена? I негативна, і позитивна відповіді провокують багато більш загальне та складне методологічне питання - принципової можливості синтезу наук про природу і наук про дух. А в його межах і питання про можливість єдиних підстав вважати науками („science”) і такі сфери досліджень, де духовна складова людської поведінки начебто очевидна (власне „humanitis”) і таких, які, не зважаючи на зовнішню схожість, щодо наявності такої складової, викликатимуть обгрунтовані сумніви (власне „science”).

А оскільки саме до цієї (духовно-душевної) складової часто апелюють цілі напрямки соціологічної думки, приміром «розуміюча соціологія» з її родоначальником М. Вебером, то актуалізується і питання про критерії науковості не тільки щодо таких напрямків, а й до соціології як науки в цілому у її розумінні як humanitis.

Відповідь на питання про можливий синтез наукового знання в межax самої соціології і соціологічного знання з науковим знанням інших наук (тією ж біології), не можлива, якщо самі критерії науковості матимуть подвійні стандарти. А якщо вони однакові, то що означатиме тоді питання про специфіку цих наук? Тобто, чи можемо ми вважати такими ж науками (буквально «science») психологію з соціологією як і фізику з біологією чи це якась інша науковість?

Усі зазначені вище питання ніяк не риторичні і потребують обгрунтованих відповідей. Тут правда йде мова фактично про науки («science»), що прийнято називати класичними. Точніше б сказати про ті, які виникали в період розвитку науки, який характеризують як класичний. В період, який, скажімо, М.Мамардашвілі (Мамардашвили, 1984) і В.С. Стьопін (Стёпин, 2000) іменують вже некласичним, в усіх цих науках відбувалися дуже складні перетворення. Та ж некласична фізика, приміром фізика Ейнштейна, суттєво відрізняється від класичної фізики Ньютона. Як і неевклідові геометрії від геометрії Евкліда.

Але це найбільш відомі приклади. Не тільки фізична, а й, приміром, хімічна чи біологічна науки за два століття зазнали таких суттєвих змін, що їх порівняння з тими самими науками класичного періоду виливається у спеціальну проблему. Більше того, почали з'являтись наукові напрямки, які взагалі не вписуються у ті критерії раціональності, на яких будувалося знання вже не тільки у власне класичний період роз- 
витку науки, але й у некласичний, що і дозволяє говорити про постнекласичний період їх розвитку, з особливими характеристиками тієї ж наукової раціональності (Стёпин, 2000).

Така відносно молода наука, як кібернетика, поява якої також супроводжувалась звинуваченнями у редукціонізмі, за своїми параметрами, специфікою предмету і методу мало чим схожа на біологію чи фізику навіть у їх некласичному варіанті. Чи, приміром, такий напрямок наукових досліджень, що небезпідставно позиціонує себе як взагалі новий стиль наукового мислення - синергетика (Добронравова, 1990).

Це явища в науці, що не просто змінюють способи раціонального мислення, а задають зовсім інші, ніж ті, які були характерними для класики і не-класики, взірці та підходи до трактування як природних, так і соціальних процесів. Маючи у своїх витоках зворотний вплив уявлень про суспільство на процеси власне природні, та ж синергетика демонструє очевидний синтетичний характер підходу у дослідженні природних процесів і процесів з так званою духовно-душевною складовою. Зокрема соціальних процесів. Тобто таких, які досліджуються соціологією та психологією.

В означений вище період лінійне, а разом з цим і суб'єкт-об'єктне мислення модифікується настільки, що це дає підстави говорити про ситуацію так званого пост-методу (Ло Дж., 2015) I це стосується не тільки нових наукових напрямків, але й наук власне класичних, зокрема фізики. Через що методологічні пошуки у напрямку принципово нових підходів стають нормою. Нормою настільки, що власне наукове мислення у класичному чи некласичному його розумінні, яке врешті за певними критеріями прагнули відрізнити від філософського, а тим більше від художньообразного, якраз усе більше починає нагадувати ці його альтернативи.

Та сама космологічна «теорія вибуху» чи «теорія струн» мало схожі, якщо взагалі схожі, не тільки на механіку Ньютона, але й на теорію відносності Ейнштейна. Зокрема. Через очевидний розрив між емпіричною і теоретичною їх складовою. Причому, це зовсім не означає, що розрив цей, обумовлений технізацією і математизацією наукового знання, хоч у якійсь мірі ставить під сумнів емпіричну складову фізики як науки. Навпаки роль емпірії, емпіричних методів в науці тільки зростає.

3 іншого боку математизація досягає такого рівня, що теоретична фізика стає фактично розділом математики, що зрозуміло не дуже подобається самим фізикам, але має свої підстави. Якщо забути, що в основу математизації будь якої науки, включно з фізикою, покладені дуже складні процедури вимірювання або порівняльного кількісного аналізу співвідношень різних природних процесів, то дійсно може скластися враження про повне уособлення теоретичної фізики від фізики експериментальної. Що очевидно не так. 
Але, з іншого боку, теоретичний синтез, основною складовою якого стають синтетичні судження апріорі, долає межу між фізикою і метафізикою. Через що і питання про можливість синтезу наук про природу і наук про дух набуває дедалі більшої актуальності і гостроти. Найперше це стосується наук, сукупність яких отримала назву когнітивних, але далеко не тільки.

Метод сучасної науки часто характеризують як такий, що його ознаки багато в чому не збігаються з ознаками наукового методу класичної і некласичної доби. А пов'язаний з цим стан методології, коли ще недавні уявлення про хоча б якусь її нормативність усе більшою мірою втрачають сенс. Утім це ніяким чином не призводить до повернення релятивізму у будь яких його проявах.

Маючи справу зі специфічними, не стаціонарними, плинними об'єктами та ще й такими, зміни в яких провокуються самими методами дослідження, ми опиняємось у принципово іншій ситуації - ситуації Барона Мюнхаузена, намагаючись витягти себе з трясовини теоретичних блукань за власне теоретичне ж волосся, начебто не звертаючись до емпірії.

Уся справа полягає якраз у цьому «начебто». Міняється не тільки мова науки, стаючи суціль математичною, але інші її вихідні позиції. Поняття об’єктивності цієї позиції, відстороненості, як її характеристики, змінюється на пошуки методів, які забезпечують прийнятні форми убудованості в процес, нерозділеності суб'єкта і об'єкта. (Отрешко, 2009). Зокрема і тоді, коли самі речі починають розглядатися на ряду з людьми як, хоча і специфічні, але актанти (концепція соціального Б.Латура) (Latour, 2005). Тобто як «повноправні» учасники того чи того процесу, включно з дослідницьким. Через що художньо-образна, метафорична мова поряд з математичною поступово стає мовою науки.

Коли ми, приміром, говоримо, що якийсь вірус може змінити стан економіки світу, це претендує на вислів не у переносному смислі, а у прямому - на безумовну констатацію економічного факту. А те, що цей вірус не усвідомлює своєї ролі, перестає бути аргументом на фоні очевидного питання: чи багато людей свідомі своєї ролі у тому самому економічному процесі?

Факторний математичний аналіз не може не розглядати усі, скажімо ті самі економічні факти, не тільки як наявні і незаперечні, а й поперше, як пов'язані між собою, а по-друге, як такі, що активно, поряд з іншими фактами, впливають, на те саме економічне життя, економічний процес в цілому. Сам цей процес, маючи багато складових, стає зрозумілим і передбачуваним (хоча б з певною ймовірністю) тільки тоді, коли ми матимемо змогу зафіксувати певні його параметри через відповідні індикатори його складових. А врешті розробити такий математичний 
апарат, який міг би дозволити спрогнозувати можливі напрямки розвитку зазначеного процесу.

I, знову таки, очевидно, що наші розрахунки стають можливими лише за наявності сучасних технічних засобів, які $є$ штучними, а ніяк не суто природними феноменами. Таким чином межа між природним і неприродним в науці постійно розмивається, що не може не вплинути на межі самих наук - природничих, технічних, соціальних і гуманітарних. Передусім, зрозуміло, за рахунок експансії математичного і технічного знання в усі ці науки.

\section{Наукова картина світу і синтез соціального знання}

Але ж прогноз, про який йшлося вище мало чим відрізняється від, скажімо, прогнозу існування планет, придатних для органічного чи й розумного життя. Що ж стосується різних концепцій еволюції Всесвіту, його етапів, то сучасна наука, спираючись на здавалося б не прямий фізичний експеримент (часто експеримент лише мислиннєвий) та негативні наслідки втручання людини в екологію Землі, намагається прогнозувати і еволюцію клімату на Землі і можливість зустрічі з інопланетними цивілізаціями. Знову таки, суто науковими, доказовими методами. Відповідно і методологічна база таких наукових досліджень розробляється виходячи з наявних можливостей саме сучасної науки і техніки у їх єдності.

Синтетичний метод, бурхливий розвиток якого символізував появу поряд з теологією науки Нового часу, оновлений і збагачений, відіграє тут особливу роль. Разом з синтезом емпіричного знання, через методики індуктивного висновку, ніколи не повного, усе більшого значення набуває теоретичний синтез, що не претендуючи на повноту, створює їі ерзац - цілісне бачення без повноти такого висновку. А тому в основі цієї повноти часто бачать не стільки раціональні, певним чином прораховані кроки, а те, що називають «інтелектуальною інтуїцією».

В сучасних теоретичних побудовах ні сучасна фізика, ні сучасна біологія, ні будь яка інша наука, як і сто чи триста років назад, не можуть опертися хоча б на якусь повноту емпіричного знання. Але об’єм знання теоретичного, дозволяє сьогодні скласти таку наукову картину світу, в якій кожне наступне досягнення емпіричної науки врешті може і часто знаходить своє місце. Це дуже схоже на те, як це було у Г.Гегеля, з його філософською, спекулятивною системою. А якщо і не знаходить, то це призводить (вже на відміну від гегелівської системи, яка домінувала над емпіричними фактами) до змін в усій системі теоретичного знання, стимулюючи новий його теоретичний синтез. 
Очевидно, що у того ж Гегеля духовність має практичну природу, а виявлення сутності речі прямо пов'язано з виявленням цієї її природи. Спроба Гегеля, слідом за Шелінгом трактувати фізичні явища як несформовані духовні пов'язана саме з цим. А синтез фізичної і духовної складової, здійснений ним в спекулятивній формі в межах так званого абсолютного ідеалізму, має дуже важливі складові. Передусім, логічну і практичну. Ці складові, зокрема через критичне до них ставлення, відіграли першочергову роль в становленні багатьох соціальних концепцій. Зокрема марксизму і позитивізму.

Але будь яка нова наукова картина світу стає можливою тільки в результаті чергового синтезу наукового знання різних галузей науки. I основою його завжди так чи інакше виступають синтетичні теорії в кожній окремій галузі науки, що тільки і може стати базою для подальших найширших узагальнень, прикладом чого є, приміром фізична «Теорія всього».

Так виникає наукова картина світу, поряд, припустимо, з теологічною. А в певних світоглядних моделях це призводить до синтезу і цих двох, здавалося б принципово розбіжних позицій - наукової і теологічної. Більше того, якщо мати на увазі суперечливий характер різних теологічних вчень, то наукова картина світу може виявитись навіть шляхом до їх поєднання (у того ж Гегеля). Це, зрозуміло, розмиває цілісність знання наукового, але є платою за світоглядну єдність.

Особливу роль тут відіграє знання соціальне. Тому не випадково йдеться про специфічну соціальну картину світу (Отрешко, 2009) Маючи яскраво виражений перформативний характер (Дудина, 2012), воно не тільки впливає на світоглядну позицію окремого індивіда, а й у сукупності з природничим, технічним і, зрозуміло, гуманітарним знанням, часто стає базовим у спробах наукових узагальнень, зокрема прогнозів розвитку людства. Без синтетичних зусиль стосовно самого соціального знання такі узагальнення і прогнози стають неможливими.

Та, з одного боку, такої кількості і таких принципово різних найбільш загальних соціальних теоретичних концепцій (власне концепцій соціального) немає в жодній природничій і технічній науці. А з іншого - очевидна вже більш як піввікова тенденція до їх синтезу, що хоча і стала характерною особливістю розвитку соціального знання в наш час, домінуючою тільки прагне стати. І хоча ці дві складові процесу становлення сучасної теоретичної соціології (її схильність до диференціації та інтеграції) часто взаємодоповнюють одна одну, процес теоретичного синтезу соціально-гуманітарного знання ще тільки набирає обертів.

Й саме на цьому фоні стали виокремлювати цілий клас таких теорій, які назвали «синтетичними» (Иванов, 2005). 3'явившись тільки у другій половині минулого століття, вони, правда, мало спростили загальну си- 
туацію теоретичного розмаїття в соціології. Але, тим не менше тенденція до синтезу соціального знання стала ще більш очевидною.

Але, з іншого боку, намагання хоч якось пояснити і систематизувати зазначену вище багатоманітність соціальних теоретичних концепцій, мало своїм наслідком спробу використати з цією метою, запропоноване Т.Куном поняття парадигми. У зв'язку з цим стан, в якому опинилась соціальна наука, було позначено, як стан «багатопарадигмальності». Це, безперечно певним чином полегшило можливість класифікації соціальних вчень, увійшовши у підручники з теоретичної соціології (Иванов, 2005).

Тим не менше є усі підстави вважати такий підхід надмірним спрощенням не тільки тлумачення концепції Т.Куна, а й ситуації багатоманітності соціального теоретичного знання, що залишає в тіні проблему його синтезу.

\section{Складність процесу теоретичного синтезу соціального знання}

Суть ситуації, яка склалася в теоретичній соціології, багато більш складна, ніж це уявляється виходячи з концепції багатопарадигмальності соціального знання. Є безліч підходів до класифікації основних напрямків розробки проблем теоретичної складової соціологічної науки. Починаючи зі спеціальних досліджень (Девятко, 2003) до фундаментальних оглядів (Йоанс, 2011; Ритцер, 2002) до невеликих підручників (Иванов, 2005).

Оскільки наявні підходи можуть різнитися настільки, що звести їх докупи, хоча б не до одного, а до декількох знаменників (основ класифікації) виявляється часто безнадійною справою, то концепція полі- метамульті- або багато-парадигмальності начебто ставить усе на свої місця, пояснюючи цю багатоманітність тим, що ми маємо справу просто з різними парадигмами - різними взірцями, на які орієнтуються різні колективи науковців в дослідженні соціальних явищ і процесів.

Різна трактовка багатопарадигмальності (їі типологізація) стосовно соціального знання не змінює загального підходу - не зважаючи на специфіку цього знання, поняття парадигми, вироблене на основі аналізу розвитку знання природничо-наукового, як вважається, може бути застосоване до аналізу і знання соціального. Навіть не зважаючи на те, що плюралізм самих соціальних парадигм вимушено починають доповнювати вже плюралізмом самих соціальних типологій (Мельников, 2017).

Безумовно трактування соціального в межах структурного функціоналізму принципово відрізняється від того, як соціальне розуміли в межах історичного матеріалізму. Критична теорія ніяк не збігається з тим, що загалом пропонує позитивізм у різних його модифікаціях. Теорію соціального обміну важко якось прямо зіставити з теоріями сим- 
волічного інтеракціонізму чи феноменологічною соціологією. Етнометодологія розглядає соціальне зовсім не так як теорія комунікативної дії. А теорія структурації і конструктивістський структуралізм, не зважаючи на здавалося б певні збіги у підходах, врешті виходять на різні концепції соціального.

Соціальне, як певний феномен, начебто постійно ховається, уникаючи більш менш однозначного пояснення. Воно демонструє не тільки багатоманітність проявів, але й такі характеристики, які не вписуються у жодні класифікації. Тим не менше, на зміну альтернативним концепціям усе частіше таки приходять нові і нові спроби їх теоретичного синтезу.

I хоча структурному функціоналізму протистояли, з одного боку, неомарксистскі концепції, а з іншого - феноменологічна соціологія, власне позитивістські та пост-позитивістські, ідеї подолання межі між науками про природу і людину (чи не основний камінь спотикання між ними) мали як своїх противників, так і прибічників (скажімо, К.Поппер).

В самій теоретичній соціології ця ідея знаходила своє втілення у спробах знайти баланс між системним і діяльнісним підходами. Якщо загострити питання, яке у зв'язку з цим виникало, то його можна було б сформулювати так: система дій людини (схожа на будь які, включно $з$ природними системами) обумовлює окрему дію чи навпаки окремі дії людей (їх активність) врешті обумовлюють характер цієї системи дій. Це фактично споконвічна проблема про курку і яйце, яка в межах лінійного мислення, очевидно що не має свого вирішення.

Розуміючи це, цілий ряд соціальних мислителів здійснили спробу синтезувати зазначені вище підходи, здавалося б принципово міняючи загальні засади теоретичних побудов. Так, приміром, виникли концепція комунікативної дії Ю.Габермаса і теорія структурації Е.Гіденса, в яких з різних позицій проводилась думка про єдність системи і дії.

Такою ж синтетичною теорією можна вважати і концепцію Н.Лумана, в якій проводиться думка не тільки інтеграції мікро- і макро- соціології, а й складності, невизначеності процесу комунікації, яка тим не менше підтримує певний порядок у цій системі. Завдяки цьому вибудовується концепція декількох рівнів соціальної системи: інтеракція, організація і суспільство. Тобто саме комунікація, а не просто дія чи навіть комунікативна дія, утворює соціальну систему.

Саме на цій підставі пропонується вирішення екологічних проблем - проблем взаємодії природи і суспільства, природи і людини. Аутопойесіс соціальної системи - ось те що з точки зору Н.Лумана розриває зачароване коло цієї взаємодії. Оскільки суспільство само-організована система, то людям немає до кого звертатися у взаємодії з такою ж самоорганізованою системою, якою є природа. Думка про єдність природи і людського суспільства має своїм результатом висновок про те, що саме 
людина відповідальна за вирішення екологічних проблем. А особлива роль, таким чином, у їх вирішенні випадає не просто на окрему людину, а на власне зміни у суспільстві, якщо його розглядати як систему передусім людських стосунків.

Дуже схожа думка випливає з концепції структуралізму, а тим більше з пост-структуралістських пошуків, передусім концепції М.Фуко, що закладає основи прагнення до нового синтезу концептуальних підходів. I хоча в поглядах, скажімо у Ж.Бодрійяра, напруження людського і нелюдського в суспільних стосунках досягає найбільшої гостроти, через що знову ставиться під сумнів можливість їх теоретичного синтезу, пошуки єдності продовжуються.

Так, розроблена в межах пост-структуралістських пошуків концепція дискурсивних практик стає основою подальших намагань здійснення теоретичного синтезу соціального знання як такої цілісності, де людське і не-людське могло б знайти своє місце. В супереч ідеї «кінця» або «завершення» соціального (Ж. Бодрійяр), П.Бурд'є висуває ідею соціальної практики як спонтанної дії з реалізації габітуальних схем мислення і практики. Таким чином, в межах так званого конструктивістського структуралізму він знову шукає синтез суб’єктивної дії і об’єктивної структури суспільних стосунків.

Останні складаються хоча і невимушено, стихійно, тобто так само як і природні само-організовані системи, в основу їх покладені системи практик, які утворюють власне фізичні відмінності способів життя окремих індивідів. I діють вони завжди саме у цих фізичних межах вже історичних практик. Таким чином соціальний простір, хоча і відмінний від простору фізичного, утворює з ним єдине ціле.

У цьому розмаїтті концепцій особливе місце займає підхід до розуміння соціального Б. Латура (Latour, 2005). 3 одного боку її можна було б класифікувати як «синтетичну», а з іншого - вона випадає з жодної вже існуючої класифікації. Основна її особливість полягає в тому, що вона являє собою приклад не тільки пост-некласичного синтезу соціального і природничо-наукового знання, а і цих різновидів знання зі знанням техніко-технологічним. I усе це в межах потужного руху, який отримав назву під абревіатурою STS (Science and Technology studies або Science, Technology and Society) або „наука - техніка - суспільство”.

В цілому ж, таким чином, тенденціям усе більшого теоретичного розмаїття протистоїть інша тенденція - теоретичного синтезу, коли кожна не тільки наступна теорія соціального, а і та, що виникає паралельно, узагальнюючи, щось втрачають і разом з тим отримують від інших. Тому, не звівши усе це розмаїття у єдине ціле, коли компоненти систем, їх окремі елементи можна було б розглянути виходячи з якоїсь більш 
менш очевидної підстави, ми так і не отримуємо хоча б до якоїсь гармонії концепцій соціальності.

Тому концепція багатопарадигмальності, хоча і виявляється певним чином прийнятною для підручників з теоретичної соціології, оскільки відбиває статику, наявний стан зазначеної вище ситуації, ніяк не схоплює динаміку процесу, ніяк не пояснюючи складні перипетії становлення теорії соціального як певного синтезу соціального знання. Через що перспективи такого синтезу в межах зазначеної концепції богатопарадигмальності стають достатньо примарними.

\section{Концепиія «багатопарадигмальності» та історична і логічна складові поняття парадигми}

I це зрозуміло, оскільки концепція багатопарадигмальності соціальної науки ігнорує засадничі елементи самої концепції парадигми у Т.Куна. Найперше це те, що саме це поняття, запозичене з лінгвістики, вироблялось Куном на протиставленні природничих і соціально-гуманітарних наук. (Кун, 2001). А тому, коли йдеться про парадигми у цих науках, то ми отримуємо парадоксальну ситуацією. Якщо в природничих науках парадигми слідують одна за одною, змінюючись в часі, то «парадигми», приміром в соціальних науках, не просто співіснують, заперечуючи одна одну, а взагалі у своєму розвитку не мають, за термінологією Куна стадії, «нормальної науки».

Врешті стан цих наук виявляється станом перманентної революції, оскільки за Куном, наявність одночасно хоча б двох парадигм, характеризує саме такий стан - стан наукової революції. Утім на усе це, як правило, не дуже звертають увагу, продовжуючи, особливо в навчальній літературі, розглядати різні концепції соціального, а разом з тим і соціальної науки як різні парадигми в соціології.

Вже поняття «дисциплінарної матриці» у того ж Т.Куна, та його ідея так званого «переключення гештальту», які він вводить у свою концепцію у післямові до другого видання своєї основної роботи «Структура наукових революцій», є багато більш адекватними щодо стану у соціальній науці сьогодні, ніж модне, як на тепер, поняття парадигми.

Тим не менше і саме поняття парадигми у Т.Куна не можна розуміти спрощено. Воно має принаймні два, безперечно взаємопов'язані, але різні аспекти - історичний (сам напрямок у філософії науки, який розробляв Т.Кун називають «історичним») і логічний, на який, як правило мало звертають уваги. Якщо перший складає найбільш популярну сторону концепції Куна - історія науки з його точки зору це зміна парадигм, то другий аспект, залишають в тіні, хоча він не менш важливий. Йдеться 
про те, що будь яка парадигма безперечно пов’язана з попередньою і наступною певною логікою.

Приміром, коли фізику Ейнштейна і квантову механіку вважати новим взірцем для вирішення проблем (новою парадигмою), що принципово відрізняються від фізики Ньютона, то не треба забувати і про їх тісний зв'язок. Що та ж сама, концепція відносності Ейнштейна прямо пов'язана з вченням про відносність у Галілея і Ньютона. Втіленням цього зв'язку є реалізована Ейнштейном ідея загальної і спеціальної теорії відносності. А тому ми не просто в різних ситуаціях фізичних взаємодій виходимо з різних парадигм. А в одному випадку враховуємо, а іншому не враховуємо певні параметри через практично кількісно мізерні, або, навпаки, кількісно значущі показники цих параметрів.

Це один і той самий фізичний процес на який ми дивимось з різних позицій - такого, що рухається з постійною швидкістю (покоїться) чи прискоренням (сповільненням) спостерігача. А тому отримуємо у різних випадках для нас різні параметри цього процесу, які можуть мати у зв'язку з цим і різне значення - суттєве або не суттєве. Ця обставина методологічно виражена через принцип відповідності Н.Бора, який регулює співвідношення математичних апаратів нової та старої теорії так, що коли нові параметри набувають граничних значень (нуль або нескінченність), математичний апарат нової теорії переходить в математичний апарат старої теорії.

Бор виходив з досвіду саме спеціальної теорії відносності, яка використовує ту обставину, що при наданні швидкості світла нескінченного значення (що природно для розгляду процесів з малими швидкостями порівняно з швидкістю світла) принципи відносності Лоренца переходять у принципи відносності Галілея. При формулюванні першого варіанту квантової теорії Н.Бор використав цей принцип як евристичний, ввівши новий параметр постійну Планка. При наданні їй нульового значення з формул квантової механіки (для мікросвіту) ми отримуємо формули механіки класичної (макроскопічної).

Наявність та співвідношення різних складових загальної і спеціальної теорії відносності фіксує цей зв'язок старої і нової парадигми. А тому в результаті ми маємо складну структуру знання, яка знаходиться у певному взаємозв'язку в межах здавалося б різних теоретичних побудов. Кун їх назвав парадигмами, які не просто історично слідують одна за одною, але й виявляються логічно тісно пов'язаними між собою.

Зокрема не врахуванням цієї обставини викликана критика концепції Т. Куна, приміром з боку К. Поппера. Ця критика виходить з того, що в науці завжди є певні, історично не локалізовані структурні елементи, які ми не можемо ігнорувати. I саме вони, будучи незмінними, часто обумовлюють логічні, раціонально вивірені зв'язки нового і старого зна- 
ння, а не тільки ірраціональні інтуїтивні стрибки від однієї парадигми до іншої. Тому між різними здавалося б парадигмами завжди присутній тісний внутрішній зв'язок, про який ніколи не можна забувати.

\section{Можливі шляхи теоретичного синтезу соціального знання}

Пошуки тієї клітинки, яка, будучи присутня в усіх концептуальних теоретичних схемах вирішення соціальних проблем, водночас могла б претендувати на основу їх єдності, задача не проста. Але саме це відкриває шлях до теоретичного синтезу соціального знання, такої синтетичної соціальної теорії, яка б могла увібрати в себе основані на різних концептуальних схемах теоретичні концепції. Не заперечуючи їх і водночас не відтворюючи ту їх какофонію, яка $є$ тим, що першим впадає в око. I хоча так це виглядає тільки зовні, навіть певною мірою карикатурно, але ситуацію, яку ми можемо спостерігати в теоретичній соціології, як і усяка карикатура, схоплює дуже точно.

Дихотомією, що могла б претендувати на цю клітину, вже називалась альтернатива активності і пасивності (Пипич, 2006). Але наступним питанням, яке у цьому зв'язку виникає $є$, прямо пов'язане з цією альтернативою, питання про співвідношення людського і не-людського компоненту в соціальних теоріях, про що йшла мова вище. Одне з вирішень пропонує у цьому зв'язку Б.Латур, який надає не-людям значення актантів. Соціальне таким чином набуває смислу складеного з різнорідних (штучних і природних) компонентів процесу, в якому ці актанти певним чином діють, утворюючи гібридні (людино-не-людські) цілісності.

В цих гібридах, одначе, позиція людини стає дещо невизначеною. 3'являється можливість перекладення відповідальності за результати дій на не визначеного агента (актанта), що, пояснюючи тенденцію руйнації соціуму, закриває перспективу його відтворення на відповідних засадах - саме людських стосунках. 3 точки зору загального соціологічного підходу, коли ми констатуємо реальний процес, в якому дійсно практично не можливо розрізнити природне і штучне, людське і не-людське, позначена вище проблема відповідальності дійсно розмита.

Утім, якщо взяти, приміром, юридичну науку то ми не можемо залишити цю проблему не вирішеною. А тому і зусилля з синтезу соціального, передусім теоретичного знання не можуть бути здійснені не тільки без врахування досвіду попередніх спроб такого синтезу, а й без врахування такого ж досвіду в інших, зокрема природничих науках.

Тому за аналогією з вирішенням проблеми, умовно кажучи, «міжпарадигмального синтезу», здійсненого в фізичній науці А.Ейнштейном, можна було б запропонувати виокремлення двох різних концептуальних позицій в цілісній, єдиній теорії соціального. Перша з них виходить 
з того, що усі вимірювальні процедури будуються в межах суто людських соціальних стосунків, складаючи спеціальну теорію соціального.

Оскільки у цьому зв'язку багатоманітність концептуальних позицій стосовно трактування соціального може бути зведена в кінцевому підсумку лише до двох - центральної і не центральної (периферійної) позиції людини в системі її взаємодії з іншими людьми та природно-технічними об’єктами, можна говорити і про дві взаємопов'язані частини єдиної теорії соціального.

Тобто, розглядатися, з одного боку, з позиції людино-вимірності, а 3 іншого - позиції, коли місце людини в системі координат рівноправне з не-людьми, розмите. У другому випадку ми, якраз і отримуємо таку теорію соціального, яку можна назвати загальною. Яскравий її приклад синергетична теорія соціального.

Такий принцип побудови синтетичної соціальної теорії дає можливість уникнути багатьох непорозумінь, які випливають з концепції багатопарадигмальності наукового соціального знання.

Ми отримуємо більш менш чіткий критерій можливого теоретичного синтезу, який випливає з самого характеру соціального знання, його можна б сказати гібридного характеру. Але разом з тим ми отримуємо і принцип зведення одних теоретичних концепцій соціального до інших, прибираючи або навпаки додаючи певні параметри виміру соціальності. Зі свого боку, такого роду синтез забезпечує можливість подальших синтетичних зусиль в напрямку синтезу соціального знання зі знанням природничим, гуманітарним та технічним.

Останнє стає основою розрізнення теоретичних узагальнень стосовно елементів в самому суспільстві, які мають, з одного боку, умовно кажучи «штучний», а з іншого, також умовно - «природний» характер. Ця проблема вже мала своє висвітлення (Пипич, 2012).

В цілому ж можна зробити висновок, що сама установка на теоретичний синтез природничого, соціального, гуманітарного і технічного знання має досі недооцінений евристичний потенціал.

\section{Посилання:}

Девид Джери; Джулия Джери (1999а) Большой социологический словарь. Т.2. Москва: ВЕЧИ-АСТ, 360.

Девид Джери, Джулия Джери (1999b) Большой социологический словарь. Т.2. Москва: ВЕЧИ-АСТ, 254.

Девид Джери, Джулия Джери (1999с) Большой социологический словарь. Т.2. Москва: ВЕЧИ-АСТ, 257.

Добронравова И.С. (1990) Синергетика: становление нелинейного мышления, Киев, «Либідь».

Дудина В.И. (2012) Эпистемологическая реконфигурация социального знания: от репрезентации к перформативности. Журнал социологии и социальной антропологии. Т12. №3. 
Иванов Д.В. (2005) Парадигмы в социологии. Учебное пособие. Омск: Из-во ОмГУ. Кун Т. (2001) Структура научных революций. М.:О00 «Из-во АСТ», 16.

Латур Б. (2015) Пастер: Война и мир микробов, с приложением «Несводимого». СПб.: Из-во Европейского у-та.

Ло Дж. (2015) После метода: беспорядок и социальная наука (Пер. с англ.) М.:Ин-т Гайдара.

Мамардашвили М. (1984) Класический и некласический идеал рациональности. Тбилиси «Мсценереба».

Мельников А. (2017) К проблеме метапарадигмальной типологизации социологического знания. Вісник КНУ Т.Шевченка. Социология, 1(8), 17-22.

Отрешко Н.Б. (2009) Трансформация эпистемологических оснований социологии: субъект, метод познания, картина социального мира. К.

Пипич А. (2012) Великі та малі соціальні машини. Філософська думка, №6, 49-65.

Пипич А. (2006) Теорія соціального опосереднення як різновид філософської позиції «постмарксизму» (методологичний аспект). В: Цінності громадянського суспільства і моральний вибір: український досвід. К. 239-243.

Стёпин В.С. (2000) Теоретическое знание. Москва: Прогресс-Традиция.

Харрисон Дж. (1979) Биология человека. М.:Мир, 106-124.

Latour B. (2005) Reassembling the Social. An introduction to Actor-Network-Theore OXFORD.

\section{References:}

David Jerry, Julia Jerry $(1991,1999)$ The Great Sociological Dictionary. V.2. Moscow: EVENINGS-AST, 360 [in Russian].

David Jerry, Julia Jerry $(1991,1999)$ The Great Sociological Dictionary. V.2. Moscow: VECHI-AST, 254 [in Russian].

David Jerry, Julia Jerry $(1991,1999)$ The Great Sociological Dictionary. V.2. Moscow: VECHI-AST, 257 [in Russian].

Dobronravova I.S. (1990) Synergetics: the formation of nonlinear thinking. K. "Lybid" [in Russian].

Harrison J. (1979) Biology of Man. M.: World, 106-124 [in Russian].

Ivanov D.V. (2005) Paradigms in sociology. Tutorial. Omsk: From the Omsk State University [in Russian].

Kun T. (2001) The Structure of Scientific Revolutions. M.: Iz-in AST Ltd, 16 [in Russian].

Latour B. (2015) Pasteur: War and the world of germs, with the application of «Irreducible». St. Petersburg: Because of the European U-th [in Russian].

Lo J. (2015) After the method: disorder and social science. M.: Gaidar Institute [in Russian].

Melnikov. A (2017) On the problem of metaparadigmal typology of sociological knowledge. Bulletin of the National Taras Shevchenko University. T. Shevchenko. Sociology, 1 (8), $17-$ 22 [in Russian].

Mamardashvili M. (1984) Classical and non-classical ideal of rationality. Mscenereba Tbilisi [in Russian].

Otreshko N.B. (2009) Transformation of the epistemological foundations of sociology: subject, method of cognition, picture of the social world. K. [in Russian]. 
Pypych A. (2012) Large and small social machines. Philosophical thought,No 6, 49-65 [in Ukrainian].

Pypych A. (2006) The theory of social mediation as a kind of philosophical position of «post-Marxism» (methodological aspect). In: Values of civil society and moral choice: Ukrainian experience. K. 239-243 [in Ukrainian].

Stepin V.S. (2000) Theoretical knowledge. Moscow: Progress-Traditions [in Russian].

Latour B. (2005) Reassembling the Social. An introduction to Actor-Network-Theore. OXFORD.

\section{Анатолий Пипич. Пост-неклассический синтез знания и социальная наука}

Автор исходит из традиционности видения специфики социального от взглядов неокантианцев и Дильтея к различению "humanitis" и "science". Прежде всего это расхождение преодолевается через синтез знания о человеке и природе. Примером является социобиология. В пределах неклассической и постнеклассической разновидностей научного знания тенденция к теоретическому синтезу нарастает. Упоминаются кибернетика и синергетика как ориентированные на новый тип рациональности и уже в истоках по сути синтетические. Особое значение в целостной картине мира по мнению автора имеет социальное знание, перформативное по своей природе. Его теоретический синтез из-за наличия большого количества различных концепций социального, что было обозначено как его многопарадигмальность, затруднен. Имеющийся в литературе подход к его систематизации, по мнению автора, не способствует решению проблемы. Особенно если в картине мира учесть влияние на процесс синтеза не только знания о человеке и природе, а и технического знания.

Предлагается вернуться к истокам самого понятия парадигмы у Т.Куна, её не только исторического (парадигмы меняются во времени), но и логического аспекта (того, что они внутренне связаны между собой). В качестве примера приводится теория относительности Эйнштейна, где эта связь двух парадигм (принципы относительности Галилея-Ньютона и Эйнштейна) составляет единство через взаимосвязь общей и специальной теории относительности.

На основании чего автор предлагает взять за образец указанную выше структуру для построения синтетической теории социального, в которой специальная и общая теория социального составляли бы определенную целостность. Первая часть (специальная теория) должна иметь прямое отношение к человеку, а у другая бы рассматривала человеческие отношения на основе знания о природе и техники (общая теория социального).

Ключевые слова: специфика социального знания, «humanities» и «science», теоретический синтез знания, научная картина мира, парадигма, мультипарадигмальность, специальная и общая теория социальности. 


\section{Anatoliy Pypych. Post non-classical synthesis of knowledge and social science}

The author proceeds from the traditional consideration of the specifics of the social from the views of the Neo-Kantians and Dilthey on the distinction between "humanities" and "science". First of all, this difference is overcome by the synthesis of knowledge of human and nature, sociobiology being an example of that. Within non-classical and post-non-classical varieties of scientific knowledge, the tendency for theoretical synthesis is being increased. Cybernetics and synergetics are mentioned as oriented towards a new type of rationality and being essentially synthetic already in their origins.

The author argues that the social knowledge, performative in its nature, obtains particular importance in the holistic world-picture. Its theoretical synthesis is difficult to achieve due to the large number of different concepts of the social, which has been designated as its multiparadigmality. According to the author, the approach to systematization proposed by sources does not contribute to solving the problem. Especially when taking into account within the world-picture the impact on the synthesis process caused not only by the knowledge of human and nature, but by technical knowledge as well.

It is suggested to return to the origins of the very concept of paradigm by $\mathrm{T}$. Kuhn, its not only historical (paradigms change over time) but logical aspect as well (they are internally related). An example provided is A. Einstein's theory of relativity, where this connection of the two paradigms (both Galileo-Newton's and Einstein's principles of relativity) constitutes a unity through the interconnection of general and special relativity.

On this ground the author proposes to take the mentioned structure as a model for constructing a synthetic theory of the social, in which a special and general theory of the social would constitute a certain integrity. The first part (the special theory) would have a direct relation to human, and the second part would deal with human relations in the light of the knowledge of nature and technology (general theory of the social).

Keywords: Specificity of social knowledge. "Humanities" and "science". Theoretical knowledge synthesis, scientific picture of the world, paradigm, multiparadigmalmality, special and general theory of sociality

Пипич Анатолій Іванович - кандидат філософських наук, доцент кафедри філософії та методології науки Київського національного університету імені Тараса Шевченка.

Anatoliy Pypych, Candidate of Philosophy, Associate Professor of the Department of Philosophy and Methodology of Science at Taras Shevchenko National University of Kyiv. 